DOI: https://doi.org/10.47405/mjssh.v6i12.1211

\begin{tabular}{|c|c|}
\hline & Malaysian Journal of Social Sciences and Humanities (MJSSH) \\
\hline Malaysian Journal of & Volume 6, Issue 12, December 2021 \\
\hline (MJ-SSH) & e-ISSN : 2504-8562 \\
\hline & $\begin{array}{l}\text { Journal home page: } \\
\text { www.msocialsciences.com }\end{array}$ \\
\hline
\end{tabular}

\title{
Sorotan Literatur Bersistematik: Kaedah Pembelajaran Berasaskan Masalah dan Kemahiran Berfikir Aras Tinggi
}

\author{
Valerie Thomas' ${ }^{1}$, Shahlan Surat ${ }^{1}$ \\ ${ }^{1}$ Fakulti Pendidikan, Universiti Kebangsaan Malaysia (UKM), Malaysia \\ Correspondence: Valerie Thomas (valrasaur@gmail.com)
}

\begin{abstract}
Abstrak
Pembelajaran berasaskan masalah (PBM) yang dibangunkan berdasarkan Teori Konstruktivisme Sosial menggalakkan komunikasi dua hala di mana interaksi sosial berlaku antara guru dan pelajar serta pelajar dan pelajar. Kajian ini dijalankan bertujuan untuk meninjau keberkesanan kaedah pembelajaran berasaskan masalah terhadap kemahiran berfikir aras tinggi. Artikel dari tahun 2017 sehingga 2020 telah diperolehi dari empat pangkalan data iaitu EBSCOhost, ERIC, Google Scholar dan Research Gate. Sebanyak 20 artikel telah dipilih berdasarkan tiga peringkat dalam Model PRISMA iaitu peringkat pengenalpastian, saringan dan rangkuman. Dapatan analisis menunjukkan bahawa kaedah pembelajaran berasaskan masalah berupaya meningkatkan kemahiran berfikir aras tinggi murid. Pembelajaran menggunakan kaedah ini berupaya merangsang pelajar untuk menggunakan kemahiran berfikir pada aras yang tinggi seperti mengaplikasikan dan menganalisis permasalahan, menilai keputusan dan mencipta idea baharu bagi menyelesaikan masalah. Walau bagaimanapun, pelaksanaan kaedah ini memerlukan kesediaan pelajar untuk terlibat secara aktif dalam menyuarakan pendapat serta berkongsi idea dalam proses pengajaran dan pembelajaran. Manakala peranan guru dilihat sebagai elemen yang penting bagi memastikan pelaksanaan kaedah ini mencapai objektif pembelajaran. Peranan guru sebagai pemudahcara yang aktif dalam memberi bimbingan kepada pelajar akan menjadikan suasana pembelajaran kekal positif dan dinamik. Oleh yang demikian, guru perlu membuat perancangan yang sistematik bagi membiasakan pelajar menggunakan kaedah pembelajaran berasaskan masalah.
\end{abstract}

Kata kunci: pembelajaran berasaskan masalah, kemahiran berfikir aras tinggi, pembelajaran abad ke-21, teori konstruktivisme sosial

\section{Systematic Literature Review: Problem-Based Learning and Higher Order Thinking Skills}

\begin{abstract}
Problem-Based Learning (PBL) is developed based on Social Constructivism Theory which promotes two-way communication between teachers and students as well as students and students. This systematic literature review is conducted to examine the effectiveness of problem-based learning method on students' higher order thinking skills. Articles from 2017 to 2020 were obtained from four databases namely EBSCOhost, ERIC, Google Scholar and Research Gate. A total of 20 articles were selected based on three stages in the PRISMA Model which are identification, screening, and inclusion. The analysis shows that problem-based learning could improve students' higher order thinking skills. This learning method could stimulate the students to use their thinking skills such as applying,
\end{abstract}


analyzing problems, evaluating results, and creating new ideas to solve problems. However, the implementation of this method requires the students' readiness to participate actively in voicing their opinions and sharing ideas in the teaching and learning process. On the other hand, the role of the teacher is seen as an important element to ensure the implementation of this method can achieve the learning objectives. The teachers' role as active facilitators in providing guidance to the students will make the learning environment remain positive and dynamic. Therefore, teachers need to have systematic planning to familiarize students with problem-based learning.

Keywords: problem-based learning, higher order thinking skills, $21^{\text {st }}$ century skills, social constructivism theory

\section{Pengenalan}

Sehaluan dengan perkembangan Revolusi Industri 4.0, sistem pendidikan di negara tidak terkecuali dari pelbagai bentuk perubahan yang dinamik serta progresif. Perubahan ini dipandang sebagai perkembangan yang positif dan menepati keperluan semasa. Sementara itu, transformasi dalam pendidikan menggesa guru sebagai anggota pelaksana untuk menerapkan elemen kreativiti dan inovasi dengan mengamalkan kaedah pembelajaran abad ke-21 dalam bilik darjah. Dalam konteks ini, guru perlu meningkatkan kompetensi diri dengan mentransformasikan gaya pengajaran yang boleh mempengaruhi hasil pembelajaran pelajar (Mohd Yusof, Roslee \& Dayang, 2017). Ini menggambarkan bahawa strategi pengajaran dan pembelajaran (PdP) yang menggunakan pendekatan konvensional dan berpusatkan guru seperti kuliah, menghafal fakta dan menyalin nota menjadi tidak relevan lagi. Hal ini demikian kerana kaedah pengajaran dan pembelajaran yang konvensional akan mengakibatkan pelajar menjadi pasif di dalam proses PdP (Fatin Adlina, 2018). Penglibatan pasif dari pelajar tidak akan mencetuskan kemahiran berfikir kritis dan menyebabkan mereka menghafal isi pelajaran (Fajari, 2020). Kesannya, pelajar tidak berupaya untuk menggunakan pemikiran kritis dan kreatif sepenuhnya dalam proses pembelajaran. Oleh itu, guru wajar memastikan kaedah PdP dilaksanakan berdasarkan pembelajaran abad ke-21 (Abdul Jalil, Abdul Ghani \& Isrihan, 2019). Pembelajaran abad ke-21 (PAK21) dibentuk berdasarkan kerangka 4C yang merangkumi kreativiti (creativity), pemikiran kritis (critical thinking), kolaborasi (collaboration) dan komunikasi (communication) (Jessica \& Zamri, 2021). Dalam pada itu, PAK21 memfokuskan strategi PdP yang berpusatkan pelajar serta menumpukan kepada kemahiran berfikir aras tinggi murid (Sylviana \& Siti Mistima, 2020). Pembelajaran berasaskan masalah (PBM) merupakan strategi PdP yang menyokong ciri-ciri PAK21. Hal ini demikian kerana kaedah PBM memberi masalah sebenar kepada pelajar dengan menerapkan pembelajaran menggunakan kemahiran berfikir kritis, menyelesaikan masalah, memperoleh pengetahuan dan konsep penting dari isi pelajaran (Darhim, Prabawanto \& Susilo, 2020).

\section{Sorotan Literatur}

Pembelajaran berasaskan masalah (PBM) merupakan salah satu strategi pengajaran dan pembelajaran aktif berpusatkan pelajar (Kardoyo et al., 2020) yang menggunakan masalah autentik (Bashith \& Amin, 2017) untuk merangsang pelajar bertindak sebagai penyelesai masalah serta berkemahiran dalam menggunakan pemikiran kritis untuk menyelesaikan masalah (Pebriana \& Disman, 2017). Kaedah pembelajaran ini bukanlah suatu kaedah yang baharu kerana ianya telah diperkenalkan pada tahun 1960 oleh Howard Barrow dari McMaster University Medical School yang terletak di Kanada. Kaedah pembelajaran berasaskan masalah dibangunkan berdasarkan Teori Konstruktivisme Sosial yang dipelopori oleh Lev Vygotksy. Terdapat tiga prinsip-prinsip Teori Konstruktivisme Sosial yang diterapkan dalam kaedah pembelajaran berasaskan masalah antaranya adalah pembelajaran berpusatkan pelajar, interaksi sosial menerusi pembelajaran koperatif serta Zon Perkembangan Proksimal dan scaffolding. Menurut Ulger (2018) pembelajaran berasaskan masalah menjurus kepada aktiviti pengajaran dan pembelajaran yang berpusatkan pelajar di mana guru tidak mendominasi aktiviti pengajaran dan pembelajaran sepenuhnya sebaliknya berperanan untuk mendorong pelajar mengurus dan mengawal pembelajaran mereka sendiri. Oleh yang demikian, kaedah PBM mempunyai 
kecenderungan untuk menggalakkan pelajar memikul tanggungjawab terhadap pembelajaran menerusi penglibatan aktif dalam aktiviti penyelesaian masalah (Seyyedrezaie \& Barani, 2017).

Selain itu, pembelajaran koperatif merupakan asas kepada pembangunan kaedah PBM yang menyediakan platform kepada pelajar untuk berbincang dan bekerjasama dalam kumpulan yang kecil bagi menyelesaikan masalah. Menerusi kaedah PBM, pelajar akan ditempatkan dalam beberapa kumpulan kecil yang merangsang mereka untuk berinteraksi dengan ahli kumpulan untuk melakukan penerokaan dan pentafsiran terhadap topik yang dipelajari serta mengaplikasikan pengetahuan dan pengalaman dalam mencari jalan penyelesaian (Hung, Moallem \& Dabbagh, 2019). Dalam pada itu, aktiviti berkumpulan yang disyorkan dalam pembelajaran berasaskan masalah berkait rapat dengan proses Zone Proximal Development (ZPD) atau Zon Perkembangan Proksimal dan scaffolding, Dengan adanya scaffolding atau pertolongan dari ahli kumpulan yang lebih cekap dan berkebolehan, maka pelajar akan dapat membina pengetahuan dan menyelesaikan masalah yang dihadapi dengan lebih efektif. Dalam konteks ini, penglibatan aktif pelajar amat penting dalam memastikan aktiviti perbincangan dan penyelesaian masalah berlaku dengan lancar dalam kumpulan. Ini tentunya menunjukkan pelajar perlu berinteraksi dan berkolaborasi bersama dengan ahli kumpulan untuk mempelajari sesuatu yang baharu. Sebaliknya, guru hanya berperanan sebagai fasilitator dan bukannya penentu dalam pencarian maklumat dan penyelesaian masalah (Siti Fatimah \& Jamalludin, 2020). Sepanjang pelaksanaan PBM, interaksi antara guru dan pelajar amat penting dalam mewujudkan persekitaran pembelajaran yang aktif dan positif (Khusaini, Lestari \& Agustin, 2018). Oleh itu, guru dan pelajar bertanggungjawab dalam memainkan peranan masing-masing bagi menjayakan pelaksanaan PBM dan mencapai objektif yang ditentukan dalam pembelajaran.

\section{Metod Kajian}

Dalam kajian ini, Model PRISMA (Preferred Reporting Items for Systematic Reviews and MetaAnalyses) telah digunakan dalam memulakan proses pencarian dan penyaringan artikel secara sistematik dan komprehensif. Prosedur melalui model semakan PRISMA dibahagikan kepada tiga peringkat iaitu (1) peringkat pengenalpastian (identification), (2) peringkat penyaringan (screening) dan (3) peringkat rangkuman (included).

\section{Peringkat Pengenalpastian}

Terdapat empat enjin carian digunakan untuk mencari dan mendapatkan sumber data iaitu EBSCOhost, ERIC, Google Scholar dan Research Gate. Selanjutnya, kata kunci seperti 'problembased learning', 'critical thinking', 'higher order thinking skill', pembelajaran berasaskan masalah, kemahiran berfikir aras tinggi dan pemikiran kritis digunakan sebagai strategi dalam pencarian literatur. Penggunaan kata kunci yang sedemikian memudahkan pencarian literatur yang berkait rapat serta relevan dengan tajuk kajian yang dikaji. Menerusi pangkalan data yang digunakan, sebanyak 40 artikel telah diperoleh dan dirumuskan seperti dalam Jadual 1.

Jadual 1: Jumlah artikel bagi setiap pangkalan data

\begin{tabular}{ll}
\hline Pangkalan Data & Jumlah Artikel \\
\hline EBSCOhost & 10 \\
ERIC & 10 \\
Google Scholar & 15 \\
Research Gate & 5 \\
\hline
\end{tabular}

\section{Peringkat Penyaringan}

Bagi peringkat penyaringan, terdapat beberapa kriteria pemilihan literatur seperti jenis dokumen, bidang, tahun penerbitan, bahasa dan liputan negara. Kriteria yang ditentukan secara tidak langsung membantu pengkaji untuk melakukan penyaringan artikel dengan lebih berkesan dan tertumpu ke arah objektif kajian. Jadual 2 menunjukkan rumusan bagi kriteria pemilihan literatur bagi kajian ini. 
DOI: https://doi.org/10.47405/mjssh.v6i12.1211

Jadual 2: Kriteria Kelayakan dan Penyisihan Literatur

\begin{tabular}{lll}
\hline Kriteria & Kelayakan & Penyisihan \\
\hline Jenis dokumen & Artikel jurnal & $\begin{array}{l}\text { Artikel seminar, prosiding dan } \\
\text { kajian sistematik }\end{array}$ \\
Bidang & Sains Sosial, Psikologi, & Kejuruteraan, Perubatan dan \\
& Ekonomi dan Kemanusiaan & Undang-undang \\
Tahun Penerbitan & 2017 hingga 2021 & \\
& (5 tahun ke belakang hingga & \\
& tahun terkini) & \\
Bahasa & Bahasa Melayu & Selain dari Bahasa Melayu \\
& Bahasa Inggeris & dan Bahasa Inggeris \\
Liputan negara & Dalam negara & Tidak berkenaan \\
& Luar negara & \\
\hline
\end{tabular}

Sumber: Diadaptasi daripada Nur Izzati, Shahida dan Latifa (2020)

\section{Peringkat Rangkuman}

Di peringkat rangkuman, pengkaji meneliti semula artikel yang dikumpulkan untuk dianalisis. Setelah selesai peringkat penyaringan, 20 artikel dipilih untuk disintesiskan. Rajah 1 ialah carta alir prosedur peringkat pengenalpastian, saringan dan rangkuman berdasarkan Model PRISMA.

Rajah 1: Carta Alir Model PRISMA
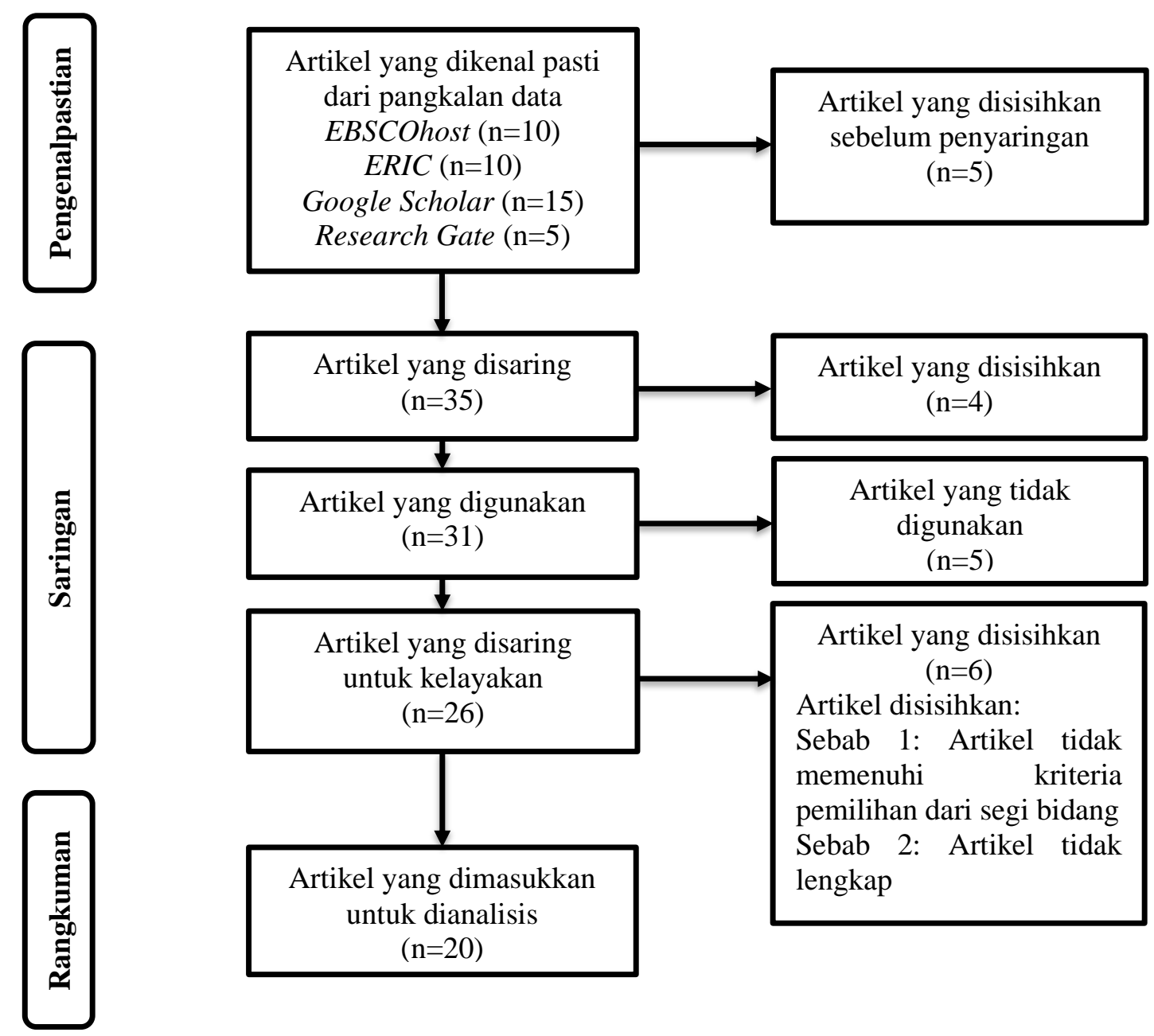

Sumber: Diadaptasi daripada Page et al. (2021) 


\section{Hasil Kajian}

Analisis yang dijalankan terhadap 20 artikel yang terpilih meliputi latar belakang peserta kajian, populasi negara, reka bentuk penyelidikan dan reka bentuk kajian, kaedah pengumpulan data, pengintegrasian teknik dalam PBM serta mekanisme pengukuran KBAT.

\section{Latar Belakang Peserta Kajian}

Berdasarkan Jadual 3, seramai 1283 orang peserta terlibat dalam kajian yang dijalankan dari 20 artikel. Sebanyak 3 artikel melibatkan 388 pelajar sekolah rendah, 11 artikel melibatkan 592 pelajar sekolah menengah dan 6 artikel melibatkan 303 pelajar pra-siswazah. Manakala julat umur peserta kajian boleh dikategorikan kepada tiga iaitu 9-11 tahun, 14-17 tahun dan 18-22 tahun. Peserta yang menyertai kajian merupakan pelajar dari pelbagai bidang pengkhususan misalnya bidang Ekonomi, Sains Sosial, Seni Visual, Perakaunan, Pendidikan Islam, Matematik dan Sains. Kepelbagaian bidang pengkhususan ini menunjukkan kaedah PBM tidak tertumpu kepada bidang perubatan semata-mata. Kaedah ini telah berkembang dan diadaptasi mengikut kesesuaian kandungan pembelajaran serta keperluan pelajar.

Jadual 3: Julat umur peserta kajian

\begin{tabular}{|c|c|c|c|}
\hline Peserta & Julat Umur & Jumlah & Pengarang \\
\hline Pelajar sekolah rendah & $9-11$ & 388 (3 artikel) & $\begin{array}{l}\text { Pebriana \& Disman (2017), } \\
\text { Mulyanto, Gunarhadi \& } \\
\text { Indriayu (2018), Yonanda, Yuliati } \\
\text { \& Saputra (2019) }\end{array}$ \\
\hline $\begin{array}{l}\text { Pelajar sekolah } \\
\text { menengah }\end{array}$ & $14-17$ & $\begin{array}{l}592(11 \\
\text { artikel })\end{array}$ & $\begin{array}{l}\text { Bashith \& Amin (2017), Fatin } \\
\text { Adlina (2018), Siti Faridah \& } \\
\text { Hartini Jaafar (2018), Lubis, Irwanto } \\
\text { \& Harahap (2019), Saputra et al. } \\
\text { (2019), Dakabesi \& Louise (2019), } \\
\text { Siti Fatimah \& Jamalludin (2020), } \\
\text { Lapuz \& Fulgencio (2020), } \\
\text { Kasmiati, Tahril \& Vanny (2020), } \\
\text { Afdareza, Yuanita \& Maimunah } \\
\text { (2020), Alsarayeh (2021) }\end{array}$ \\
\hline Pelajar pra-siswazah & $18-22$ & $30(6$ artikel $)$ & $\begin{array}{l}\text { Ulger (2018), Darhim, Prabawanto } \\
\& \text { Susilo (2020), Kardoyo et al. } \\
\text { (2020), Saputro et al. (2020), } \\
\text { Amin et al. (2020), Suryanti \& } \\
\text { Nurhuda (2021) }\end{array}$ \\
\hline
\end{tabular}

\section{Populasi Negara}

Bagi aspek populasi kajian, data dalam Jadual 4 mengenal pasti negara Indonesia sebagai negara yang banyak menggunakan kaedah PBM bertujuan untuk meningkatkan kemahiran berfikir aras tinggi pelajar. Sistem pendidikan Indonesia yang menggunakan Kurikulum Tingkat Satuan Pendidikan (KTSP) pada tahun 2006 telah digantikan dengan Kurikulum 2013 (K-13) yang menekankan aspek kognitif, afektif dan psikomotor bersesuaian dengan transformasi pada abad ke-21 (Aprillianti, 2018). Kurikulum sebelumnya dianggap tidak seimbang kerana hanya menumpukan kepada aspek kognitif sahaja. Maka sistem pendidikan menggunakan K-13 yang baharu dilihat berupaya untuk menyediakan masyarakat Indonesia yang produktif, kreatif, inovatif dan kreatif (Afdareza, Putri \& Maimunah, 2020). Pada masa yang sama, penekanan terhadap kemahiran berfikir dalam sistem pendidikan di negara kita dapat dilihat dalam kandungan PPPM 2013-2025. Hal ini menunjukkan persamaan yang diketengahkan oleh kedua-dua sistem pendidikan di negara Malaysia dan Indonesia adalah penekanan terhadap kemahiran berfikir dan kemahiran menyelesaikan masalah yang merupakan kemahiran abad ke-21 yang boleh diasah menerusi strategi PdP yang berpusatkan pelajar. 
Jadual 4: Populasi negara

\begin{tabular}{|c|c|c|}
\hline Negara & Jumlah & Pengarang \\
\hline Indonesia & 14 & $\begin{array}{l}\text { Bashith \& Amin (2017), Pebriana \& Disman (2017), Mulyanto, } \\
\text { Gunarhadi \& Indriayu (2018), Yonanda, Yuliati \& Saputra (2019), } \\
\text { Lubis, Irwanto \& Harahap (2019), Saputra et al. (2019), Dakabesi } \\
\text { \& Louise (2019), Darhim, Prabawanto \& Susilo (2020), Kardoyo } \\
\text { et al. (2020), Kasmiati Tahril \& Vanny (2020), Afdareza, Yuanita } \\
\text { \& Maimunah (2020), Saputro et al. (2020), Amin et al. (2020), } \\
\text { Suryanti \& Nurhuda (2021) }\end{array}$ \\
\hline Malaysia & 3 & $\begin{array}{l}\text { Siti Faridah \& Hartini Jaafar (2018), Fatin Adlina (2018), } \\
\text { Siti Fatimah \& Jamalludin (2020) }\end{array}$ \\
\hline Filipina & 1 & Lapuz \& Fulgencio (2020) \\
\hline Jordan & 1 & Alsarayeh (2021) \\
\hline Turki & 1 & Ulger (2018) \\
\hline
\end{tabular}

\section{Reka Bentuk Penyelidikan dan Reka Bentuk Kajian}

Kebanyakan pengkaji-pengkaji lepas mengkaji keberkesanan pembelajaran berasaskan masalah menggunakan reka bentuk penyelidikan berbentuk kuasi-eksperimen dengan reka bentuk ujian prapasca bagi kumpulan-kumpulan tidak seimbang. Menerusi kajian berbentuk kuasi-eksperimen, praeksperimen dan eksperimen, pelajar ditempatkan dalam kumpulan eksperimen dan kawalan. Pelajar dalam kumpulan eksperimen akan menerima rawatan iaitu belajar menggunakan intervensi PBM manakala pelajar dalam kumpulan kawalan belajar menggunakan kaedah konvensional (Siti Faridah \& Hartini Jaafar, 2018). Dalam pada itu, reka bentuk penyelidikan yang lain seperti pra-eksperimen, eksperimen dan kajian tindakan turut digunakan dan ditunjukkan seperti dalam Jadual 5.

Jadual 5: Reka Bentuk Penyelidikan dan Reka Bentuk Kajian

\begin{tabular}{|c|c|c|c|}
\hline $\begin{array}{l}\text { Reka Bentuk } \\
\text { Penyelidikan }\end{array}$ & Reka Bentuk Kajian & Jumlah & Pengarang \\
\hline \multirow[t]{2}{*}{$\begin{array}{l}\text { Kajian Kuasi- } \\
\text { Eksperimen }\end{array}$} & $\begin{array}{l}\text { Ujian Pra-Pasca bagi } \\
\text { kumpulan-kumpulan } \\
\text { tidak seimbang }\end{array}$ & 9 & $\begin{array}{l}\text { Bashith \& Amin (2017), Pebriana \& } \\
\text { Disman (2017), Siti Faridah \& } \\
\text { Hartini Jaafar (2018), Fatin Adlina } \\
\text { (2018), Kasmiati, Tahril \& Vanny } \\
\text { (2020), Saputro et al. (2020), Amin } \\
\text { et al. (2020), Alsarayeh (2021), } \\
\text { Suryanti \& Nurhuda (2021) }\end{array}$ \\
\hline & $\begin{array}{l}\text { Satu kumpulan kawalan } \\
\text { Ujian Pasca }\end{array}$ & 1 & Dakabesi \& Louise (2019) \\
\hline $\begin{array}{l}\text { Kajian Pra- } \\
\text { Eksperimen }\end{array}$ & $\begin{array}{l}\text { Satu kumpulan kawalan } \\
\text { Pra Ujian-Pasca Ujian }\end{array}$ & 4 & $\begin{array}{l}\text { Ulger (2018), Saputra et al. (2019), } \\
\text { Siti Fatimah \& Jamalludin (2020), } \\
\text { Afdareza, Yuanita \& Maimunah } \\
\text { (2020) }\end{array}$ \\
\hline $\begin{array}{l}\text { Kajian } \\
\text { Eksperimen }\end{array}$ & $\begin{array}{l}\text { Satu kumpulan kawalan } \\
\text { Pra Ujian dan Pasca } \\
\text { Ujian }\end{array}$ & 3 & $\begin{array}{l}\text { Mulyanto, Gunarhadi \& Indriayu } \\
\text { (2018), Yonanda, Yuliati \& Saputra } \\
\text { (2019), Lapuz \& Fulgencio (2020) }\end{array}$ \\
\hline & $\begin{array}{l}\text { Dua kumpulan kawalan } \\
\text { Pra Ujian dan Pasca } \\
\text { Ujian }\end{array}$ & 1 & $\begin{array}{l}\text { Darhim, Prabawanto \& Susilo } \\
\text { (2020) }\end{array}$ \\
\hline Kajian Tindakan & $\begin{array}{l}\text { Model Mulyasa (2009) } \\
\text { Model Kemmis \& } \\
\text { McTaggart (1988) }\end{array}$ & $\begin{array}{l}1 \\
1\end{array}$ & $\begin{array}{l}\text { Kardoyo et al. (2020) } \\
\text { Lubis, Irwanto \& Harahap (2019) }\end{array}$ \\
\hline
\end{tabular}




\section{Kaedah Pengumpulan Data}

Kajian dari 20 artikel telah menggunakan kaedah ujian pra dan pasca untuk mengenal pasti perbezaan tahap penguasaan KBAT pelajar sebelum dan selepas menerima rawatan. Seterusnya, terdapat beberapa kajian yang menggunakan pemerhatian untuk mengumpul data dan dilakukan dengan memerhati tingkah laku pelajar serta guru dalam proses pembelajaran (Kasmiati, Tahril \& Vanny, 2020). Merujuk kepada Jadual 6 beberapa kaedah pengumpulan data yang lain seperti soal selidik, temu bual dan dokumentasi turut digunakan dalam kajian lepas untuk merekodkan perubahan pelajar dari segi kognitif dan tingkah laku sebelum dan selepas menggunakan kaedah PBM dalam PdP.

Jadual 6: Kaedah Pengumpulan Data

\begin{tabular}{|c|c|c|}
\hline Kaedah Pengumpulan Data & Jumlah & Pengarang \\
\hline Ujian pra dan pasca & 19 & $\begin{array}{l}\text { Bashith \& Amin (2017), Pebriana \& Disman } \\
\text { (2017), Siti Faridah \& Hartini Jaafar (2018), Farah } \\
\text { Adlina(2018), Ulger (2018), Mulyanto, Gunarhadi } \\
\text { \& Inriayu (2018), Yonanda, Yuliati \& Saputra } \\
\text { (2019), Lubis, Irwanto \& Harahap (2019), Saputra } \\
\text { et al.(2019), Dakabesi \& Louise (2019), Siti } \\
\text { Fatimah \& Jamalludin (2020), Darhim, Prabawanto } \\
\text { \& Susilo (2020), Lapuz \& Fulgencio (2020), } \\
\text { Kasmiati, Tahril \& Vanny (2020), Afdareza, } \\
\text { Yuanita \& Maimunah (2020), Saputro et al. (2020), } \\
\text { Amin et al. (2020), Alsarayeh (2021), Suryanti \& } \\
\text { Nurhuda (2021) }\end{array}$ \\
\hline Pemerhatian & 6 & $\begin{array}{l}\text { Pebriana \& Disman (2017), Lubis, Irwanto \& } \\
\text { Harahap (2019), Darhim, Prabawanto \& Susilo } \\
\text { (2020), Kardoyo et al. (2020), Kasmiati, Tahril \& } \\
\text { Vanny (2020), Afdareza, Yuanita \& Maimunah } \\
\text { (2020) }\end{array}$ \\
\hline Soal selidik & 4 & $\begin{array}{l}\text { Yonanda, Yuliati \& Saputra (2019), Lubis, Irwanto } \\
\text { \& Harahap (2019), Siti Fatimah \& Jamalludin } \\
\text { (2020), Afdareza, Yuanita \& Maimunah (2020) }\end{array}$ \\
\hline Temu bual & 4 & $\begin{array}{l}\text { Pebriana \& Disman (2017), Yonanda, Yuliati \& } \\
\text { Saputra (2019), Siti Fatimah \& Jamalludin (2020), } \\
\text { Kardoyo et al. (20200 }\end{array}$ \\
\hline Dokumentasi & 2 & $\begin{array}{l}\text { Yonanda, Yuliati \& Saputra (2019), Darhim, } \\
\text { Prabawanto \& Susilo (2020) }\end{array}$ \\
\hline
\end{tabular}

\section{Pengintegrasian Teknik dalam Kaedah PBM}

Terdapat 5 kajian yang mengintegrasikan beberapa teknik dalam pelaksanaan kaedah PBM. Pengintegrasian teknik dalam kaedah PBM dilihat berupaya untuk memantapkan lagi hasil kajian terhadap kemahiran berfikir aras tinggi pelajar. Kajian Siti Fatimah dan Jamalludin (2020) mendapati penggunaan teknologi Web 2.0 dapat menarik minat pelajar untuk menggunakan aplikasi dalam pembelajaran serta menjimatkan masa kerana pelajar boleh membuat perbincangan dan berinteraksi dengan ahli kumpulan serta guru di luar waktu persekolahan. Seterusnya, kajian Yonanda, Yuliati dan Saputra (2019) yang mengintegrasikan buku komik dalam kaedah PBM dilihat berkesan dalam membuat hubung kait antara bahan pembelajaran dengan situasi sebenar pelajar yang digambarkan melalui situasi yang dialami oleh watak-watak dalam komik. Dari sudut lain, kajian Saputra et al. (2019) membincangkan Model Jigsaw dapat memupuk pembelajaran koperatif dengan lebih sistematik di mana setiap pelajar mempunyai tugas dan peranan yang berbeza dalam kumpulan. Hal ini menyebabkan penglibatan pelajar dapat dipantau dan menggalakkan semua kumpulan bekerjasama dalam satu kumpulan besar yang sama. Manakala alat pembelajaran yang dibangunkan dalam kajian Afdareza, Yuanita dan Maimunah (2020) membantu pelajar dalam topik geomteri serta menunjukkan hasil yang memberangsangkan terhadap kemahiran berfikir aras tinggi pelajar. Hal ini demikian kerana alat 
pembelajaran yang dibina adalah berdasarkan silibus, rancangan pengajaran, lembaran kerja, media pembelajaran serta ujian pencapaian. Ini memudahkan guru untuk melaksanakan kaedah PBM dengan lebih teratur bagi mencapai objektif pembelajaran. Dalam pada itu, penilaian rubrik yang digunakan dalam kajian Suryanti dan Nurhuda (2021) mempunyai kelebihan dalam mencapai hasil pembelajaran dan memastikan pelajar menggunakan KBAT dalam pembelajaran. Penilaian rubrik dalam bentuk deskriptif mempunyai keterangan dan kriteria kerjaya yang perlu dicapai oleh pelajar. Ini tentunya membolehkan guru dan pelajar untuk mengetahui aras pencapaian dalam pembelajaran. Penggunaan penilaian rubrik ini juga membantu pelajar untuk mengurus dan menentukan pembelajaran secara kendiri. Dalam konteks ini, pengintegrasian teknik dalam PBM merupakan inisiatif yang boleh diguna pakai oleh guru kerana kesemuanya mempunyai kelebihan yang tersendiri.

Jadual 7: Pengintegrasian Teknik dalam kaedah PBM

\begin{tabular}{ll}
\hline Teknik Pengaplikasian PBM & Pengarang \\
\hline Buku komik & Yonanda, Yuliati \& Saputra (2019) \\
Model Jigsaw & Saputra et al. (2019) \\
Teknologi Web 2.0 & Siti Fatimah \& Jamalludin (2020) \\
Alat Pembelajaran & Afdareza, Yuanita \& Maimunah (2020) \\
Penilaian Rubrik & Suryanti \& Nurhuda (2021) \\
\hline
\end{tabular}

\section{Mekanisme Pengukuran KBAT}

Jadual 8 menyenaraikan beberapa jenis mekanisme pengukuran KBAT yang digunakan dalam kajian lepas bagi mengukur penguasaan KBAT pelajar. Kebanyakan kajian lepas menggunakan ujian pra dan pasca bagi menentukan perubahan tahap KBAT pelajar sebelum dan selepas didedahkan dengan kaedah PBM. Terdapat pelbagai bentuk ujian pra dan pasca yang diadaptasi dan digubal oleh pengkaji lepas seperti penulisan esei, Ujian Pemikiran Kreatif Torrance, Inventori Penyusunan Pemikiran Kritikal California serta Instrumen Kemahiran Berfikir Kritis Facione. Di samping itu, bahan pembelajaran dan buku komik yang dibina berdasarkan isi pelajaran juga dijadikan sebagai alat untuk mengukur tahap penguasaan KBAT pelajar.

Jadual 8: Mekanisme Pengukuran KBAT

\begin{tabular}{|c|c|c|}
\hline $\begin{array}{l}\text { Mekanisme Pengukuran } \\
\text { KBAT }\end{array}$ & Jumlah & Pengarang \\
\hline Ujian Pra dan Pasca & 16 & $\begin{array}{l}\text { Bashith \& Amin (2017), Pebriana \& Disman } \\
\text { (2017), Siti Faridah \& Hartini Jaafar (2018), Fatin } \\
\text { Adlina (2018), Ulger (2018), Mulyanto, } \\
\text { Gunarhadi \& Indriayu (2018), Lubis, Irwanto \& } \\
\text { Harahap (2019), Saputra et al. (2019), Dakabesi \& } \\
\text { Louise (2019), Siti Fatimah \& Jamalludin (2020), } \\
\text { Darhim, Prabawanto \& Susilo (2020), Lapuz \& } \\
\text { Fulgencio (2020), Kasmiati, Tahril \& Vanny } \\
\text { (2020), Saputro et al. (2020), Amin et al. (2020), } \\
\text { Suryanti \& Nurhuda (2021) }\end{array}$ \\
\hline Bahan Pembelajaran & 3 & $\begin{array}{l}\text { Afdareza, Yuanita \& Maimunah (2020), Alsarayeh } \\
\text { (2021), Kardoyo et al. (2020) }\end{array}$ \\
\hline Buku Komik & 1 & Yonanda, Yuliati \& Saputra (2019) \\
\hline
\end{tabular}

\section{Perbincangan Kajian}

Dapatan dari 20 artikel kebanyakan mengenal pasti pembelajaran berasaskan masalah sebagai kaedah pengajaran dan pembelajaran yang mampu meningkatkan kemahiran berfikir aras tinggi pelajar. Sebelum diberi pendedahan menggunakan kaedah PBM, pelajar didapati tidak menguasai kemahiran 
berfikir aras tinggi seperti mengaplikasikan, menganalisis, menilai dan mencipta. Penguasaan kemahiran berfikir pelajar yang lemah boleh dikaitkan dengan penggunaan strategi PdP yang kurang berkesan dan bersifat konvensional. Kaedah PdP sedemikian memberi kesan kepada kurangnya penglibatan aktif dari pelajar dan menyebabkan mereka hanya menggunakan kemahiran berfikir aras rendah serta mengabaikan keperluan intelektual dan kreativiti pelajar (Alsarayeh, 2021). Menerusi kaedah PBM, guru dapat menggunakan situasi permasalahan yang autentik berkaitan dengan pelajar untuk merangsang mereka menggunakan kemahiran berfikir bagi mencari langkah penyelesaian yang sesuai. Penggunaan senario yang berkaitan dengan pelajar akan memupuk perasaan ingin tahu dan merangsang kemahiran berfikir pelajar (Suhirman, Prayogi \& Asy'ari, 2021). Selari dengan kenyataan tersebut, Lapuz dan Fulgencio (2020) berpendapat keadaan sedemikian akan menjadi titik permulaan kepada proses pembelajaran di mana pelajar akan mengajukan persoalan berkaitan dengan isu yang dikemukakan dalam perbincangan. Oleh itu, permasalahan yang digunakan dalam kaedah PBM perlu bersifat autentik yang dialami oleh pelajar untuk membangkitkan minat dan perasaan ingin tahu mereka untuk terlibat dalam proses penyelesaian masalah. Di samping itu, kemahiran berfikir pelajar dapat ditingkatkan melalui aktiviti perbincangan dan kolaboratif dalam kumpulan. Hal ini tercetus apabila pelajar bekerjasama dalam kumpulan untuk berkongsi pendapat, mencari maklumat, membuat perkaitan antara pengetahuan sedia ada dengan masalah (Mohamed Ali et al., 2019) dan berusaha menyelesaikan masalah bersama (Saputro et al., 2020). Oleh hal yang demikian, pembelajaran koperatif dalam PBM akan mengasah kemahiran komunikasi serta mengembang pengetahuan pelajar menerusi pengetahuan yang dibina bersama rakan yang lain. Kasmiati, Tahril dan Vanny (2020) berpandangan bahawa aktiviti berfikir dalam kaedah PBM seperti mencari maklumat, menganalisis dan memproses data, menilai dan membuat keputusan serta membuat kesimpulan ternyata memberi kesan yang memberangsangkan terhadap kemahiran berfikir aras tinggi pelajar. Maka kaedah pembelajaran berasaskan masalah dibuktikan berkesan untuk meningkatkan kemahiran berfikir aras tinggi pelajar dan keupayaan pelajar untuk menyelesaikan masalah.

Di sebalik itu, kajian-kajian lepas turut menyenaraikan beberapa isu yang perlu diberi perhatian dalam pengendalian kaedah PBM seperti kesediaan pelajar dan peranan guru. Kajian Kasmiati Tahril dan Vanny (2020) menjelaskan pelajar berdepan dengan kesukaran untuk membuat penyesuaian diri terhadap kaedah pembelajaran yang menuntut mereka untuk terlibat secara langsung dalam perbincangan serta menerapkan kemahiran berfikir dalam penyelesaian masalah yang disediakan oleh guru. Dengan keadaan sedemikian, pendedahan kaedah PBM perlu dilakukan secara berterusan kepada pelajar bagi mengelakkan mereka merasa janggal serta memberi keyakinan kepada mereka untuk mengurus pembelajaran secara kendiri. Kaedah PBM yang berlandaskan Teori Konstruktivisme Sosial menekankan interaksi sosial antara guru dan pelajar serta pelajar dan pelajar dalam pemerolehan ilmu. Selain itu, guru memainkan peranan penting sebagai pemudahcara atau fasilitor yang menyediakan scaffolding dengan memberi tunjuk ajar kepada pelajar dalam menyelesaikan tugasan. Oleh itu, guru perlu meneliti setiap fasa pelaksanaan dan memastikan tempoh masa yang diberikan kepada pelajar mencukupi bagi mencapai objektif pembelajaran (Pebriana \& Disman 2017; Saputra et al., 2019). Kegagalan guru untuk berbuat demikian akan menyebabkan pelajar tidak berupaya untuk mengaplikasikan kemahiran berfikir sepenuhnya serta tidak mengetahui hala tuju pembelajaran dalam aktiviti PBM. Oleh hal yang demikian, guru perlu memainkan peranan sebagai pemudahcara yang aktif dan memberi scaffolding dengan cara memantau perkembangan pelajar secara individu ataupun kumpulan serta turut terlibat dalam perbincangan tanpa menentukan keputusan dan menyelesaikan masalah.

\section{Kesimpulan}

Secara keseluruhan, kajian sistematik ini mengenal pasti pembelajaran berasaskan masalah sebagai satu kaedah pengajaran dan pembelajaran yang amat bermanfaat khususnya terhadap kemahiran berfikir aras tinggi pelajar dan kemahiran menyelesaikan masalah. Hasil kajian-kajian lepas mendapati kaedah PBM berupaya merangsang pelajar untuk menggunakan kemahiran berfikir pada aras yang tinggi seperti mengaplikasikan dan menganalisis permasalahan, menilai keputusan dan mencipta idea baharu bagi menyelesaikan masalah. Dalam pada itu, kaedah PBM bukan sekadar meningkatkan KBAT pelajar malah turut menyumbang kepada peningkatan terhadap aspek lain misalnya hasil pembelajaran, 
motivasi dan tingkah laku pelajar. Kaedah PBM mendukung ciri-ciri pembelajaran abad ke-21, memupuk pembelajaran koperatif serta merangsang penglibatan aktif pelajar dalam PdP. Pembelajaran aktif ini secara tidak langsung merangsang pelajar dari segi kognitif, afektif dan psikomotor yang mendorong mereka untuk memperoleh pengetahuan baharu bukan hanya dari guru malah dari rakan yang lain. Lantaran itu, guru-guru digalakkan untuk menggunakan serta mengamalkan kaedah PBM dalam konteks pengajaran masing-masing bagi merealisasikan aspirasi pendidikan negara dalam melahirkan generasi yang mempunyai kemahiran berfikir yang tinggi dan berkemahiran dalam menyelesaikan masalah untuk berdepan dengan cabaran Revolusi Industri 4.0.

\section{Rujukan}

Abdul Jalil Ali, Abdul Ghani Kanesan Abdullah \& Isrihan Mohamed. (2019, Januari). Amalan Pengupayaan dan Autonomi Guru dalam Pembelajaran dan Pemudahcaraan Abad Ke 21. Jurnal Kepimpinan Pendidikan, 6(1), 49-58.

Afdareza, M. Y., Yuanita, P. \& Maimunah. (2020, April). Development of Learning Device Based on 21st Century Skill with Implementation of Problem Based Learning to Increase Critical Thinking Skill of Students on Polyhedron for Grade 8th Junior High School. Journal of Educational Sciences, 2(2), 273-284.

Amin, S., Utaya, S. Bachri, S. \& Susilo, S. (2020, June). Effect of Problem-Based Learning on Critical Thinking Skills and Environmental Attitude. Journal for the Education of Gifted Young Scientists, $8(2), 743-755$.

Aprillianti, L. (2018). Comparison between Concept of Evaluation on KTSP Curriculum and 2013 Curriculum. UHAMKA International Conference on ELT and CALL (UICELL), (pp. 95-109). Jakarta.

Bashith, A. \& Amin, S. (2017). The Effect of Problem Based Learning on EFL Students' Critical Thinking Skill and Learning Outcome. Al-Ta'llim Journal, 23(2), 93-102.

Dakabesi, D. \& Louise, I. S. Y. (2019, November). The Effectiveness of Problem-Based Learning Model to Increase the Students' Critical Thinking Skills. Journal of Education and Learning (EduLearn), 13(4), 543-549.

Darhim, Prabawanto, S. \& Susilo, B. E. (2020, October). The Effect of Problem-Based Learning and Mathematical Problem Posing in Improving Student's Critical Thinking Skills. International Journal of Instruction, 13(4), 103-116.

Fajari, L. E. W. (2020). The Effect of Problem-Based Learning Multimedia and Picture Media on Students' Critical-Thinking Skills Viewed from Learning Motivation and Learning Styles in Elementary School. Ilkogretim Online-Elementary Education Online, 19(3), 1797-1811.

Fatin Adlina Mokter. (2019, Mei). Keberkesanan Pembelajaran Berasaskan Masalah Terhadap Pencapaian dan Kemahiran Berfikir Aras Tinggi Pelajar dalam Penulisan Karangan Bahasa Melayu. Jurnal Pendidikan Bahasa Melayu, 9(1), 33-46.

Hung, W., Moallem, M. \& Dabbagh, N. (2019). Social Foundations of Problem-Based Learning. In The Wiley Handbook of Problem-Based Learning (Vol. 1). John Wiley \& Sons, Inc.

Jessica Dora Henry \& Zamri Mahamod. (2021). Penerapan Amalan Kreativiti, Pemikiran Kritis, Kolaborasi dan Komunikasi (4C) Pembelajaran Abad Ke-21 dalam Kalangan Guru Bahasa Melayu. Jurnal Dunia Pendidikan, 3(1), 239-248.

Kardoyo, Nurkhin, A., Mushin \& Pramusinto, H. (2020, March). Problem-Based Learning Strategy: Its Impact on Students' Critical and Creative Thinking Skills. European Journal of Educational Research, 9(3), 1141-1150.

Kasmiati, Tahril \& Tiwow, M. A. V. (2020, November). Effect of Problem Based Learning Model on the Chemical Reaction Rate toward Critical Thinking Ability of Students. Jurnal Akademika Kimia, 9(4), 183-190.

Khusaini, Lestari, S. \& Agustin, N. A. (2018). The Application of Problem-Based Learning Method to Improve Economic Learning Outcomes and Motivation. Dinamika Pendidikan, 13(2), 218-227.

Lapuz, A. M. E. \& Fulgencio, M. N. (2020, January). Improving the Critical Thinking Skills of Secondary School Students using Problem-Based Learning. International Journal of Academic Multidiciplinary Research, 4(1), 1-7. 
Lubis, R. R., Irwanto \& Harahap, M. Y. (2019, October). Increasing Learning Outcomes and Ability Critical Thinking of Students Through Application Problem Based Learning Strategies. International Journal for Education and Vocational Studies, 1(6), 524-527.

Mohd Yusof Abdullah, Roslee Talip \& Dayang Fatimah Majid. (2017). Pengaruh Transformasi Pengajaran, Kesediaan dan Kepemimpinan Guru Terhadap Penglibatan Pembelajaran Pelajar Sekolah Menengah Luar Bandar di Sabah. Jurnal Kesidang, 2, 96-202.

Mulyanto, H., Gunarhadi \& Indriayu, M. (2018). The Effect of Problem Based Learning Model on Student Mathematics Learning Outcomes Viewed from Critical Thinking Skills. International Online Journal of Education and Teaching (IOJET), 5(3), 553-563.

Nur Izzati Jamaludin, Shahida Shahmi \& Latifa Bibi Musafar Hameed. (2020). Elemen Kepercayaan Sebagai Teras Sumbangan Melalui Pendanaan Awam Bertujuan Kebajikan. Asian Journal of Accounting and Governance, 13, 55-65.

Page, M. J., Moher, D., Bossuyt, P.M., Boutron, I., Hoffman, T.C., Mulrow, C. D, et al. (2021, January 5). PRISMA 2020 explanation and elaboration: updated guidance and exemplars for reporting systematic reviews. Diakses pada 10 April 2021, dari BMJ (Open Access): http://www.prismastatement.org/PRISMAStatement/FlowDiagram

Pebriana, R. \& Disman. (2017, September). Effect of Problem Based Learning to Critical Thinking Skills Elementary School Students in Social Studies. Journal of Elementary Education, 1(1), 109118.

Saputra, M. D., Joyoatmojo, S., Wardani, D. K. \& Sangka, K. B. (2019, January). Developing CriticalThinking Skilss through the Collaboration of Jigsaw Model with Problem-Based Learning Model. International Journal of Instruction, 12(1), 1077-1094.

Saputro, A. D., Atun, S., Wilujeng, I., Ariyanto, A. \& Arifin, S. (2020). Enhancing Pre-Service Elementary Teachers' Self-Efficacy and Critical Thinking using Problem-Based Learning. European Journal of Educational Research, 9(2), 765-773.

Seyyedrezaie, S. H. \& Barani, G. (2017). Constructivism and Curriculum Development. Journal of Humanities Insights, 1(3), 119-124.

Siti Faridah \& Harini Jaafar. (2018). Kesan Pelaksanaan Pembelajaran Berasaskan Masalah Terhadap Pemikiran Kritis Pelajar Tingkatan Empat dalam Mata Pelajaran Prinsip Perakaunan. Management Research Journal, 8(1), 175-187.

Siti Fatimah Salleh \& Jamalludin Harun. (2020, February). Pembelajaran Berasaskan Masalah Menerusi Teknologi Web 2.0 dalam Mata Pelajaran Sains dan Kesannya Terhadap Tahap Kemahiran Berfikir Aras Tinggi Pelajar. Innovative Teaching and Learning Journal, 3(2), 15-29.

Suhirman, Prayogi, S. \& Asy'ari, M. (2021, April). Problem-Based Learning with Character-Emphasis and Naturalist Intelligence: Examining Students Critical Thinking and Curiosity. International Journal of Instruction, 14(2), 217-232.

Suryanti, N. \& Nurhuda. (2021, April). The Effect of Problem-Based Learning with an Analytical Rubric on the Development of Students' Critical Thinking Skills. International Journal of Education, 14(2), 665-684.

Sylviana Mantihal \& Siti Mistima Maat. (2020). Pengaruh Pembelajaran Abad Ke-21 (PAK21) Terhadap Minat Murid dalam Pengajaran dan Pembelajaran Matematik: Satu Tinjauan Sistematik. Jurnal Dunia Pendidikan, 2(1), 82-91.

Ulger, K. (2018). The Effect of Problem-Based Learning on the Creative Thinking and Critical Thinking Disposition of Students in Visual Arts Education. The Interdisciplinary Journal of Problem-Based Learning, 12(1).

Yonanda, D. A., Yuliati, Y. \& Saputra, D. S. (2019). Development of Problem-Based Comic Book as Learning Media for Improving Primary School Students' Critical Thinking Ability. Mimbar Sekolah Dasar, 6(3), 341-348. 